\title{
Urban Pollution and Ecosystem Services
}

Rebecca Wade

This is the accepted manuscript of the book chapter:

Wade, R. (2019) Urban Pollution and Ecosystem Services. In: Urban Pollution: Science and Management. John Wiley \& Sons.

Published version @ 2019 John Wiley \& Sons: https://www.wiley.com/enaf/Urban+Pollution\%3A+Science+and+Management-p$\underline{9781119260509}$

This chapter may be used for non-commercial purposes in accordance with the Wiley Terms and Conditions for Self-Archiving. 
Book Chapter.

Urban Pollution and Ecosystem Services

by Rebecca Wade

In: Urban Pollution: Science and Management

Eds. Susanne M. Charlesworth \& Colin A. Booth

Wiley Blackwell. Published 21 Dec 2018

ISBN-10: 1119260485

ISBN-13: 978-1119260486

Final Draft prior to typesetting

$<\mathrm{CN}>$ Chapter 15

$<$ CT $>$ Urban Pollution and Ecosystem Services

$<$ CA > Rebecca Wade

\section{$<$ HA $>$ 15.1. Introduction}

$<\mathrm{P}>$ Urban pollutants can degrade and inhibit ecological functions and processes. Those natural processes provide vital benefits and services to humans. The 'services' range from food and water provision, to aesthetics, cultural benefits, health and recreation opportunities, and also climate regulation (including water and air quality regulation and flood regulation). These services are referred to collectively as ecosystem services (ES). To understand the impacts of urban pollution, and the opportunities for mitigating its effects, it is important to explore the relationship between pollution and ES. This can lead to better decision-making for urban infrastructure and spaces and can provide increased opportunities for gaining multiple ES from urban environments. 
$<$ HA >15.2. Ecosystem Services, the Ecosystem Approach, and Ecosystem Service Valuation

$<\mathrm{P}>$ Ecosystem Services are the benefits provided to humans by natural systems. The use of the term ecosystem services became widespread after the publication of the Millennium Ecosystem Assessment (MA) in 2005. The focus of the MA was to assess the consequences of ecosystem change for human well-being; it provided a state-of-the-art scientific appraisal of the condition and trends in the world's ecosystems and the services they provide (MA 2005). In 2011, the UK National Ecosystem Assessment (UK NEA) provided the first analysis of the United Kingdom's natural environment in terms of the benefits it provides to society and economic prosperity in the United Kingdom. An ecosystems approach was adopted; this was designed to provide a framework for examining whole ecosystems in decision-making, and for valuing the ES they provided. The aim of this approach is to ensure that society can maintain a healthy and resilient natural environment now and for future generations (DEFRA, 2013).

$<\mathrm{P}>$ There are several different definitions and classifications of ES. Both the Millennium Ecosystem Assessment (MA, 2005), and the UK National Ecosystem Assessment (UKNEA 2011) classify ES along functional lines into the four categories of provisioning, regulating, supporting, and cultural services (MA, 2005; UK NEA, 2011). Ecosystem functions determine the capacity of a natural resource system to sustain ES that are fundamental to human wellbeing. Examples of ES include products such as food and water; regulation of floods, soil erosion, and disease outbreaks; noise reduction; and non-material benefits such as recreational, educational, cultural, and spiritual benefits in natural areas (UKNEA, 2011; URBES, 2013).

$<\mathrm{P}>$ The term 'services' is usually used to encompass the tangible and intangible benefits that humans obtain from ecosystems, which are sometimes separated into 'goods' and 'services' (UKNEA, 2011). It is clear from the findings of the MA (2005) and UKNEA (2011) that 
damage to the environment is seriously degrading the ability of natural ecosystem functions to deliver these services. It is now accepted that this degradation will have direct economic implications for the management of functions such as pollution regulation, flood protection, regulation of the chemical composition of the atmosphere, and pollination, on which human well-being directly depend (POSTnote 281). The multiple values of ES (both monetary and non-monetary) can be used to identify and assess the importance of these services for society (URBES, 2013). Table 15.1 identifies some of the different values that can be attributed to urban ES; these values, however, are not often recognised in urban planning and decisionmaking and, consequently, the impact of their loss remains invisible.

$<\mathrm{TN}>$ Table 15.1. $<\mathrm{TT}>$ Example of the multiple values that can be attributed to urban ecosystem services (ES) (adapted from URBES, 2013) ${ }^{a}$

\begin{tabular}{|l|l|}
\hline$<$ TCH>Value-type & Relevance to urban ES \\
\hline$<\mathrm{TB}>$ Economic values & $\begin{array}{l}\text { Direct or indirect monetary values provided } \\
\text { by urban ecosystems, e.g. saved costs for air } \\
\text { pollution reduction by technical solutions or } \\
\text { property damage by natural barriers to } \\
\text { environmental extremes. }\end{array}$ \\
\hline Ecological values & $\begin{array}{l}\text { Environmental outputs, which have value for } \\
\text { humans, e.g. air purification, carbon storage } \\
\text { and sequestration, water filtration, and } \\
\text { genetic diversity. }\end{array}$ \\
\hline Sociocultural values & $\begin{array}{l}\text { Moral, spiritual, aesthetic, and ethical values } \\
\text { associated with urban biodiversity and ES, } \\
\text { including emotional, affective, and symbolic } \\
\text { views attached to urban nature, as well as } \\
\text { local ecological knowledge. }\end{array}$ \\
\hline
\end{tabular}




\begin{tabular}{|l|l|}
\hline Health values & $\begin{array}{l}\text { Health benefits obtained from urban green } \\
\text { spaces, consisting of reduction of air } \\
\text { pollution, improved water quality, enhanced } \\
\text { recreation potential, physical and mental } \\
\text { health benefits of spending time in nature. }\end{array}$ \\
\hline Insurance values & $\begin{array}{l}\text { The contribution of green infrastructure and } \\
\text { ES to increased resilience and reduced } \\
\text { vulnerability to shocks, such as flooding and } \\
\text { landslides. }\end{array}$ \\
\hline
\end{tabular}

$\langle\mathrm{TFN}\rangle^{a}$ Several of these services directly reference mitigation of air and water pollution or avoidance of cost related to pollution effects in urban areas.

$<\mathrm{P}>$ The monetary and health values which ES provide can be exemplified as follows: urban vegetation moderates the local temperature and buffers noise pollution. Loss of urban vegetation can lead to economic costs due to energy demand for heating and cooling buildings, healthcare expenses related to respiratory diseases, and maintenance of expensive infrastructures to abate noise and pollution (URBES, 2013; Säumel et al., 2016). Restoring urban green spaces can provide substantial long-term benefits to cities as well as delivering non-monetary or indirect ES values (such as species diversity and richness of habitat). Among the sociocultural values, there is increased community cohesion and local ecological knowledge. Enhancing the amenity value of urban areas can also positively influence public health by promoting physical activity (Säumel et al., 2016), and increased physical and mental well-being are certainly considered as health values (URBES, 2013).

$<\mathrm{P}>$ It should be noted that ecosystem disservices are also recognised in the literature; Säumel et al. (2016) have published a comprehensive table listing ecosystem services and disservices provided by roadside vegetation, in an article on liveable and healthy urban streets. They found that some plants decreased air quality by emitting biological aerosols (volatile organic 
compounds, aeroallergens), and indeed Rogers et al. (2006) reported that plant stressors such as air pollution and increased temperatures can induce increased levels of allergenic proteins in the pollen - and thereby related health problems. Therefore, the greater the impacts of urban pollution on urban ecosystems, the greater the incidence of ecosystem disservices (at least in some cases).

$<\mathrm{P}>$ More information on ES can be accessed via the UKNEA (2011), in particular, Chapter 10 (Urban), which provides information, key messages, examples, and valuations relevant to urban ES.

\section{$<$ HA $>15.3$ Urban Impacts on ES}

$<\mathrm{P}>$ Urbanisation can have significant impacts on biodiversity and ES. Population growth, increased industry and commercialisation, and expanded provision for new housing and transport, all greatly contribute to the increasing extent of impermeable surfaces. With urban development comes increased surface run-off and pollution, associated with which is the loss of regulating and provisioning services and important cultural benefits (Davies et al., 2011). All urban areas will be subject to some of the disadvantages of populated areas, such as loss and isolation of habitats (Kong et al., 2010) and increased water and air pollution (Davies et al., 2011; Lundy and Wade, 2011); these impacts will be greater in more densely populated areas.

$<\mathrm{P}>$ Urban areas can contain rich flora that contribute significantly to biodiversity, and thus they also provide many ES benefits to humans. Urban ecosystem goods and services will differ according to urban population size, boundary, location, and surroundings. The provision of ES in urban settings depends in large part on the quality and quantity of urban green infrastructure (URBES, 2013) and also on the connectivity of green spaces. The more integrated the green 
infrastructure, the greater its potential to provide ES benefits. Figures 15.1 and 15.2 provide examples of urban green space in cities.

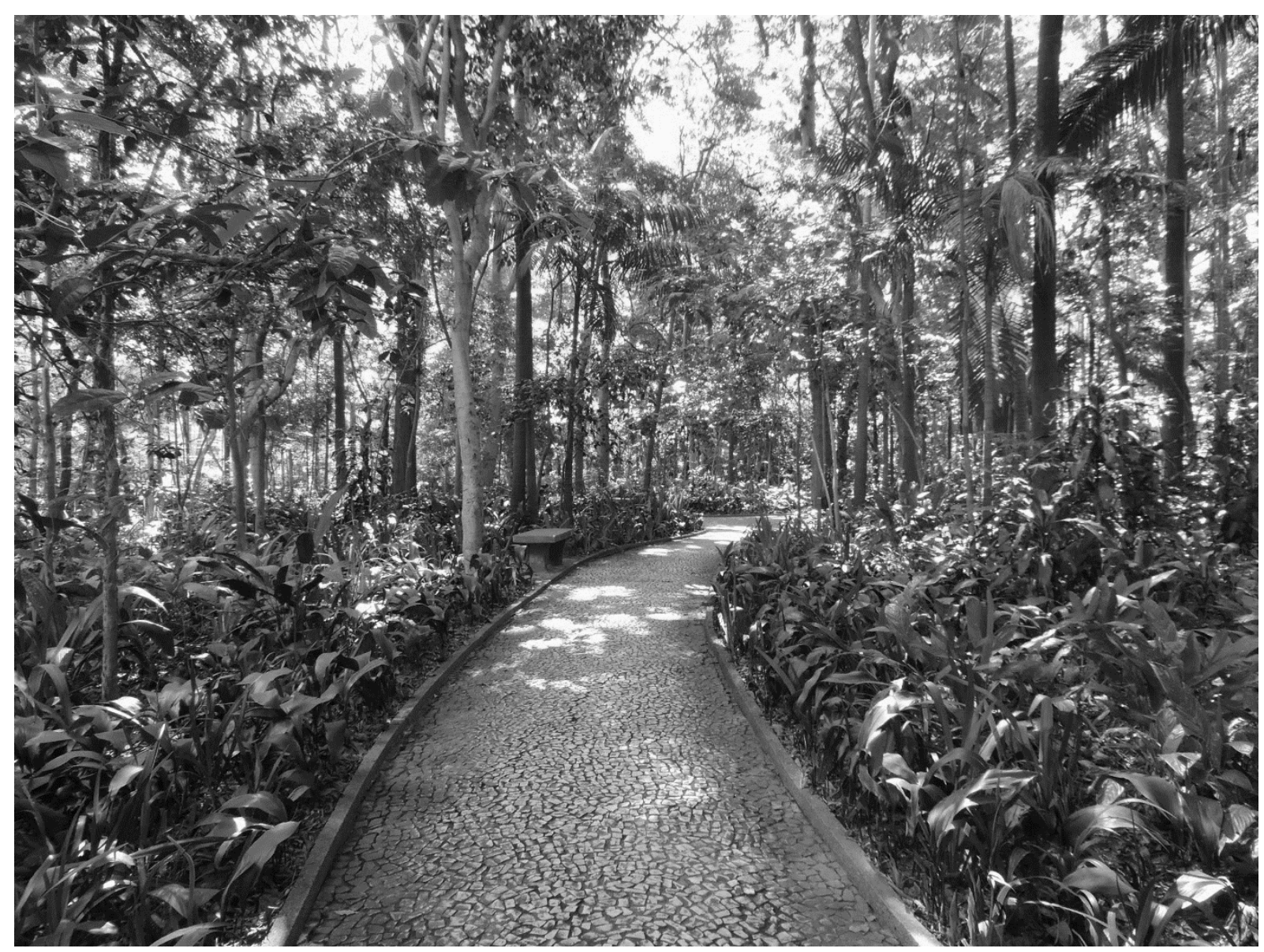

$<$ FCN $>$ Figure 15.1. $<$ FC $>$ Trianon Park, central São Paulo, Brazil. The park occupies two city blocks, it is surrounded by the concrete streets and skyscrapers (concrete forest) of Brazils' largest city. However, inside the park the air temperature is lower, the traffic fumes disappear, and even the traffic noise subsides. Trianon Park was created in 1892 and is now the only remaining piece of native Atlantic Forest (Mata Atlântica) in the area. (Photo credit: Rebecca Wade 2015). 


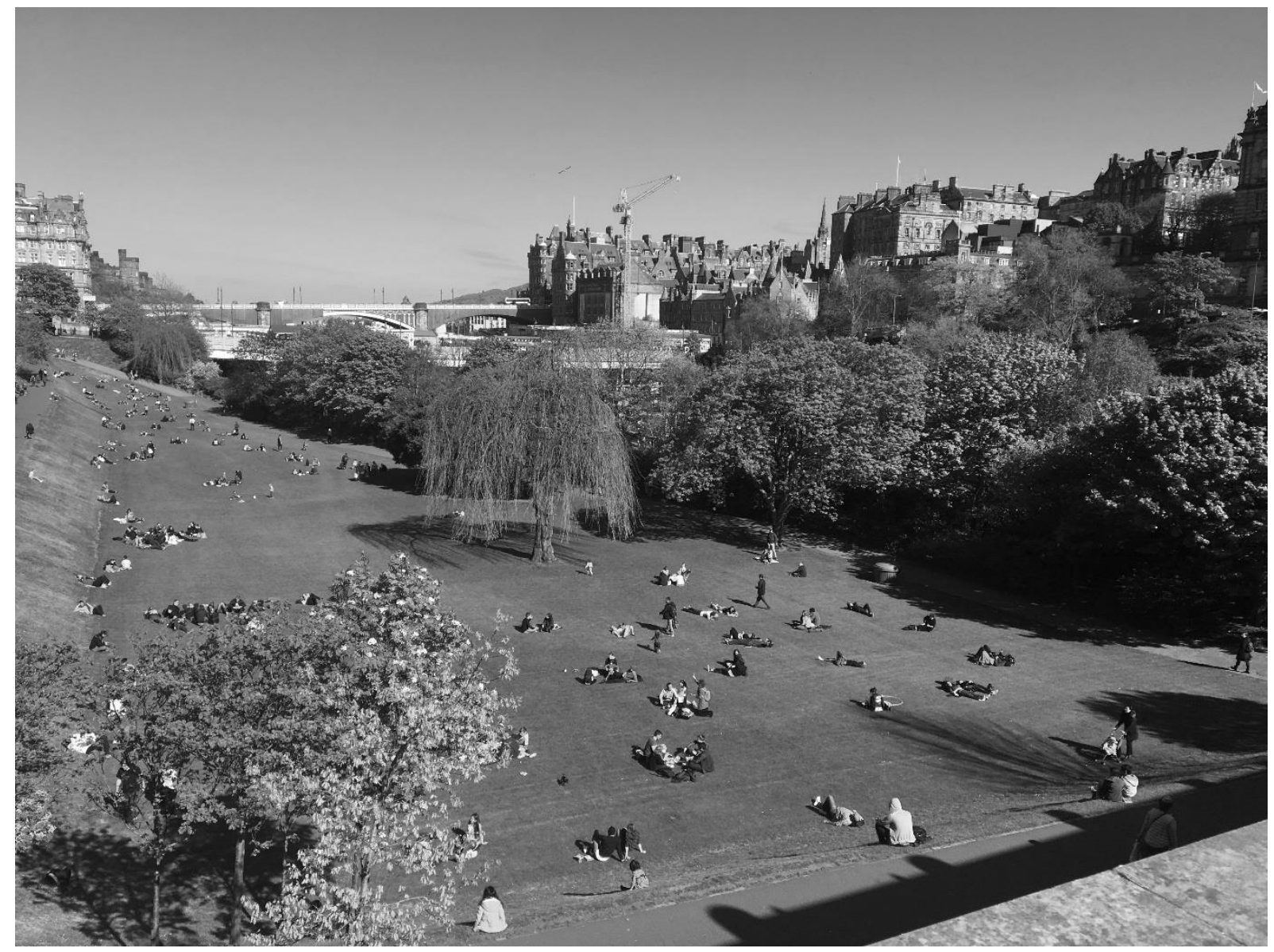

$<$ FCN $>$ Figure 15.2. $<$ FC $>$ Princes Street Gardens, a public park in the centre of Edinburgh,

Scotland, United Kingdom, in the shadow of Edinburgh Castle. The Gardens were created in the 1770s and 1820s. The prominent central location, and large size of the gardens in this busy tourist-destination capital city have ensured that the gardens are Edinburghs' best known parks with the highest visitor figures for both residents and visitors. Photo credit: Rebecca Wade 2017.

$<\mathrm{P}>$ As with ES, green infrastructure has different definitions. Broadly, green infrastructure includes parks, gardens, urban allotments, green routes or paths, urban forests, wetlands, lakes, and ponds in cities, but also natural areas - such as forests, mountains, and wetlands surrounding urban spaces. It can also be described from a planning perspective as the design elements in urban settings that contribute to the delivery of the Green Network, brought together in a placemaking masterplan (GCV GNP, no date). Green infrastructure as defined by Wise 
(2008) is 'the interconnected network of open spaces and natural areas - such as greenways, wetlands, parks, forest reserves, and native plant vegetation - that naturally manages stormwater, reduces the risk of floods, captures pollution, and improves water quality'. This definition specifically identifies pollution reduction as a feature or design element of green infrastructure.

$<\mathrm{P}>$ Urban populations draw heavily on external resources (outside the city or town boundary) for provisioning services (food and water, fuel, and fibre) and other ES. They export waste and release pollution emissions to air, water, and land that extend far beyond the urban boundary (Luck et al., 2001). The ecological footprint of urban areas is widely recognised as being much larger than the geographical area of the city or town. Urban areas also export visitors to other habitats, giving rise to associated transport pressures (pollution and infrastructure) (Davies et $a l ., 2011)$ and adding pressures to ES in other areas.

\section{$<$ HA $>15.4$ ES and Urban Pollution in the UK Legislative Context}

$<\mathrm{P}>$ In the last decade, in the United Kingdom and elsewhere, it has become increasingly possible to deliver green infrastructure elements and thereby to enhance some ESs with multiple benefits through existing legislative frameworks and requirements. For example, there is an obligation to meet surface water management legislation sustainably, from both a water quantity (flooding and drought) aspect and a water quality (pollution) perspective. In Europe, the EU Water Framework Directive has been in place for more than a decade and provides an overarching piece of legislation that aims to harmonise existing water policy and to improve water quality in all of Europe's aquatic environments (Kaika and Page, 2003). The Water Framework Directive (European Commission, 2000) affects 27 countries and marks an important trend towards an ecosystem-based approach to water policy and water resource management (Kallis and Butler, 2001). 
$<\mathrm{P}>$ However, reporting for the Royal Commission on Environmental Pollution, Goode (2006) concluded that cross-cutting guidance was needed, that it should be based firmly on the multifunctional green space network, and ensure that it provides the necessary advice for sustainability. More recently, POSTnote 376 (2011) recognised that natural resources are being impacted by a range of pressures, such as biodiversity loss and climate change. They stated that 'if governments do not monitor effectively the use or degradation of natural resource systems in national account frameworks ("environmental accounting"), the risks of incurring costs to future economic productivity are not taken into account, nor are impacts on human wellbeing' (POSTnote 376, 2011). While there is increased recognition that biodiversity and ES can contribute greatly to improve quality of life in cities, and that their maintenance will deliver economic benefit, their multiple values are usually not fully taken into account in urban policymaking (URBES, 2013).

$<\mathrm{P}>$ The UK government provide guidance for policymakers and decision-makers on using an ecosystems approach and on valuing ES (DEFRA, 2013). The Scottish government have conducted research and mapping of ES for use in decision-making across land use policy priorities (such as a low carbon economy, sustainable food production, and water management), in order to apply the work to a broad spectrum of policy sectors, including climate change, agriculture, biodiversity conservation, and water resource management. Similarly, the Welsh government includes ecosystem health and sustainability prominently in their recent Environment (Wales) Act 2016 and in their 2015 Payment for Ecosystems approach to natural resource management and decision-making.

Valuing ES benefits, or undertaking a 'natural capital' valuation, can help inform a wide range of decisions relating to management of environmental risks such as urban pollution (POSTnote $542,2016)$. However, valuation of ES and natural capital is very challenging for many reasons (e.g. data availability, spatial and temporal considerations, assessment of dis-benefits, trade- 
offs etc.) these are beyond the scope of this chapter. An overview of ES in relation to strategic improvement in urban green infrastructure elements is provided by Wentworth (2017).

\section{$<$ HA >15.5 Enhancing Urban ES to Mitigate Urban Pollution}

$<\mathrm{P}>$ Air pollution is one of the main environmental risks for human health worldwide (WHO, 2016). In this context, abatement of pollution has become of major concern especially in areas with high pollutant concentrations, typically associated with cities. Maintaining and developing green urban areas can be part of an integrative strategy to help improve air quality in cities. Trees reduce temperatures in cities by evaporating water and remove air pollutants and particulate matter via their leaves through dry deposition. In general, green plants reduce air pollutants by taking up gaseous pollutants primarily through leaf stomata. Once inside the plant, these gases react with water to form acids and other chemicals (Baldocchi et al., 1987). Green plants can also intercept particulate matter as wind currents blow them into contact with sticky plant surfaces (Bidwell and Fraser, 1972). Some of these particulates can be absorbed into the plant, while others simply adhere to the surface. Vegetation can be a temporary site for particulates as they can be re-suspended into the atmosphere by winds or washed off by rain water.

$<\mathrm{P}>$ Urban street trees, green roofs and green walls, green areas, and forests surrounding cities have the capacity to remove significant amounts of pollutants, thereby increasing environmental quality and improving human health (Pugh et al., 2012; Maes et al., 2017). Some dis-benefits have been associated with certain species of street trees, in relation to their location and management, additionally, several studies have cautioned their use for air pollution mitigation without careful consideration. 
$<\mathrm{P}>$ Pugh et al. (2012) attempted to model the complex geometry of urban surfaces in dense urban areas to gauge the effect of street-level air pollution concentrations. People are primarily exposed to pollutants at the street level, they were particularly interested in the occurrence and concentrations of air pollution in street canyons. They present results which show that incanyon vegetation offers a method to improve urban air quality substantially. The results of their analysis show that street-level reductions by as much as $40 \%$ for $\mathrm{NO}_{2}$ and $60 \%$ for $\mathrm{PM}_{10}$ are achievable using green walls, which is much higher than has been previously estimated. This suggests that the potential benefits of green infrastructure for air quality improvements have been substantially undervalued. This effect is particularly important for pollutants with atmospheric lifetimes long enough to be transported long distances, such as $\mathrm{PM}_{10}$ and ozone. Hence, greened urban canyons may ultimately experience better air quality than in surrounding rural areas. The study by Pugh et al. (2012) also considered the use of street trees as well as green walls. They conclude that street trees must be considered on a case-by-case basis. In streets with low street-level emissions (i.e., light traffic), improvements in air quality are predicted (they term this 'the filtered avenue effect'). They go on to caution that if street-level emissions are high, however, tree planting must be used with the utmost caution. The specific combination of tree species, canopy volume, canyon geometry, and wind speed, and direction must be modelled on a case-by-case basis. By not considering the adverse effects of tree planting on canyon ventilation, urban greening initiatives that concentrate on increasing the number of urban trees, without consideration of location, risk actively worsening street-level air quality while missing a considerable opportunity for air quality amelioration.

$<$ P $>$ Salmond et al. (2014) used an urban ES framework to evaluate the direct, and locally generated, ES and disservices provided by street trees. They focussed their study on the services of major importance to human health and well-being that included 'climate regulation', 'air quality regulation', and 'aesthetics and cultural services'. While recognising both benefits and 
dis-benefits, they conclude that street trees can be important tools for urban planners and designers in developing resilient and resourceful cities in an era of climatic change. Kiss et al. (2015) identified and evaluated two important regulating services of urban trees: carbon sequestration and air pollution removal in the city centre of Szeged (Hungary). The analyses revealed the main tendencies in differences between tree species considering the tree condition, which affects the service-providing capacity to a high degree. From their observations, clear cuts and complete tree alley changes are not advisable from an ES point of view.

$<\mathrm{P}>$ Many other studies have been conducted on green roofs and walls as well as street trees and other green spaces. For example, Currie and Bass (2008) conducted an early study to quantify the contribution made by green walls and green roofs on air contaminant levels in an urban neighbourhood. Results of the study indicated that grass on roofs (extensive green roofs) could augment the effect of trees and shrubs in air pollution mitigation, whereas placing shrubs on a roof (intensive green roofs) would have a more significant impact. By extension, a 10\%$20 \%$ increase in the surface area for green roofs on downtown buildings would contribute significantly to the social, financial, and environmental health of all citizens (Currie and Bass, 2008). In addition to the external benefits, green roofs provide insulation to buildings, resulting in reduced costs for heating and cooling. An experimental green roof on a municipal building in Benaguasil, Spain, resulted in a $20 \%-25 \%$ saving in electricity for the air-conditioning systems' power consumption of the building (Pérez-Navarro Gómez et al., 2015). In urban areas, roofs, a critical part of the built environment, are highly susceptible to solar radiation and other environmental changes, thereby influencing indoor comfort and energy consumption. Figure 15.3 shows a green roof installed on a school building in Xativa, Valencia region, Spain. 


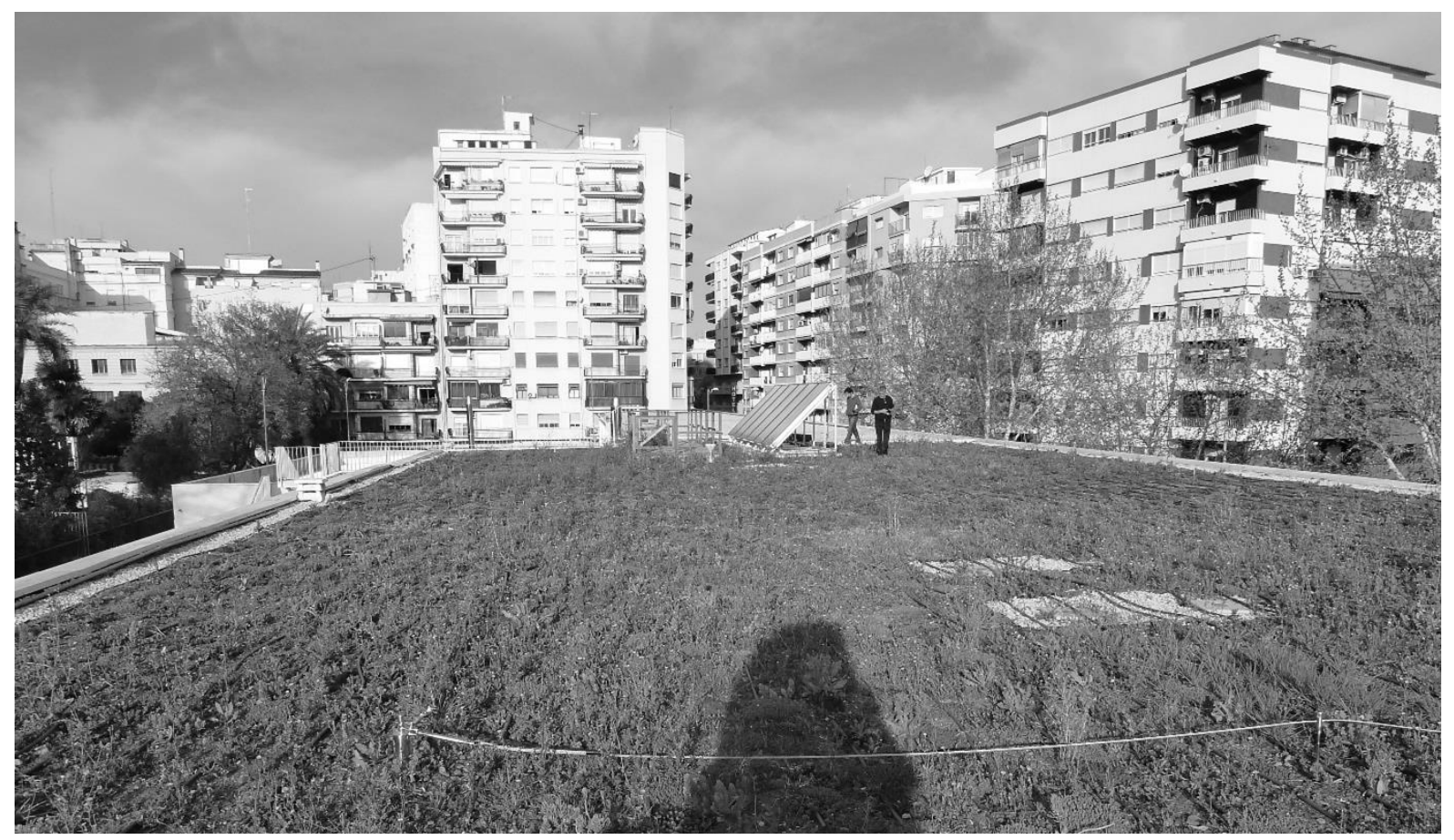

$<$ FCN $>$ Figure 15.3. $<$ FC $>$ Green roof on a school building in Xativa, Valencia region, Spain.

The green roof provides insulation to the building, and additional ecosystem service benefits are realised through air pollution mitigation (augmenting the effect of the adjacent street trees), habitat provision, aesthetic values (neighbouring residents prefer the view of green, rather than a grey roof from their apartments). Photo credit: Rebecca Wade 2013.

$<\mathrm{P}>$ Urban waterbodies are typically in receipt of diffuse pollution from a range of sources. While managing water in urban spaces is an essential infrastructure requirement, it is generally undertaken in isolation from other urban functions, and has not been considered in conjunction with other agendas, thereby missing opportunities for optimising multiple ES benefits. Because of the limits of space and the need to respond to key drivers (e.g. mitigation of diffuse pollution), more sustainable approaches to urban water management are being applied which can have multiple functions and benefits (Lundy and Wade, 2011). Many of these approaches to urban water management are driven by practical requirements, for example, water reuse and natural flood management or 'slowing the flow' generated by rainfall in impermeable urban environments to mitigate flooding/inundation from small-scale storm events. Depending on the 
location and pressures, the 'drivers' or incentives for sustainable water management will differ. For instance, drivers include the need to reduce the pressure on existing sewer infrastructure and wastewater treatment plants in terms of both capacity and treatment efficiency as well as the need to control urban diffuse pollution as part of the approach to achieving EU WFD objectives and to comply with the EU Floods Directive (EU, 2000; EU, 2007; Lundy and Wade, 2011) and the national Sustainable Flood Management policy (Scot Gov 2011).

$<\mathrm{P}>$ Given that urban waterbodies receive urban surface water run-off, they are typically in receipt of diffuse pollution from a range of sources. Sustainable drainage systems (SuDS) are now commonly in use throughout the United Kingdom and parts of Europe for new developments and redevelopments, and they provide a level of protection to existing watercourses. The SuDS features are engineered, but some vegetated features can become ES providers, particularly if they are well designed, constructed, and maintained (Jose et al., 2015). Figure 15.4 shows a stormwater management feature, a retention pond, in Ardler, Dundee, Scotland; the pond slows and retains the flow of surface run-off from the residential development. Sediments and pollutants are deposited in the pond before the water continues through the SuDS treatment train. 


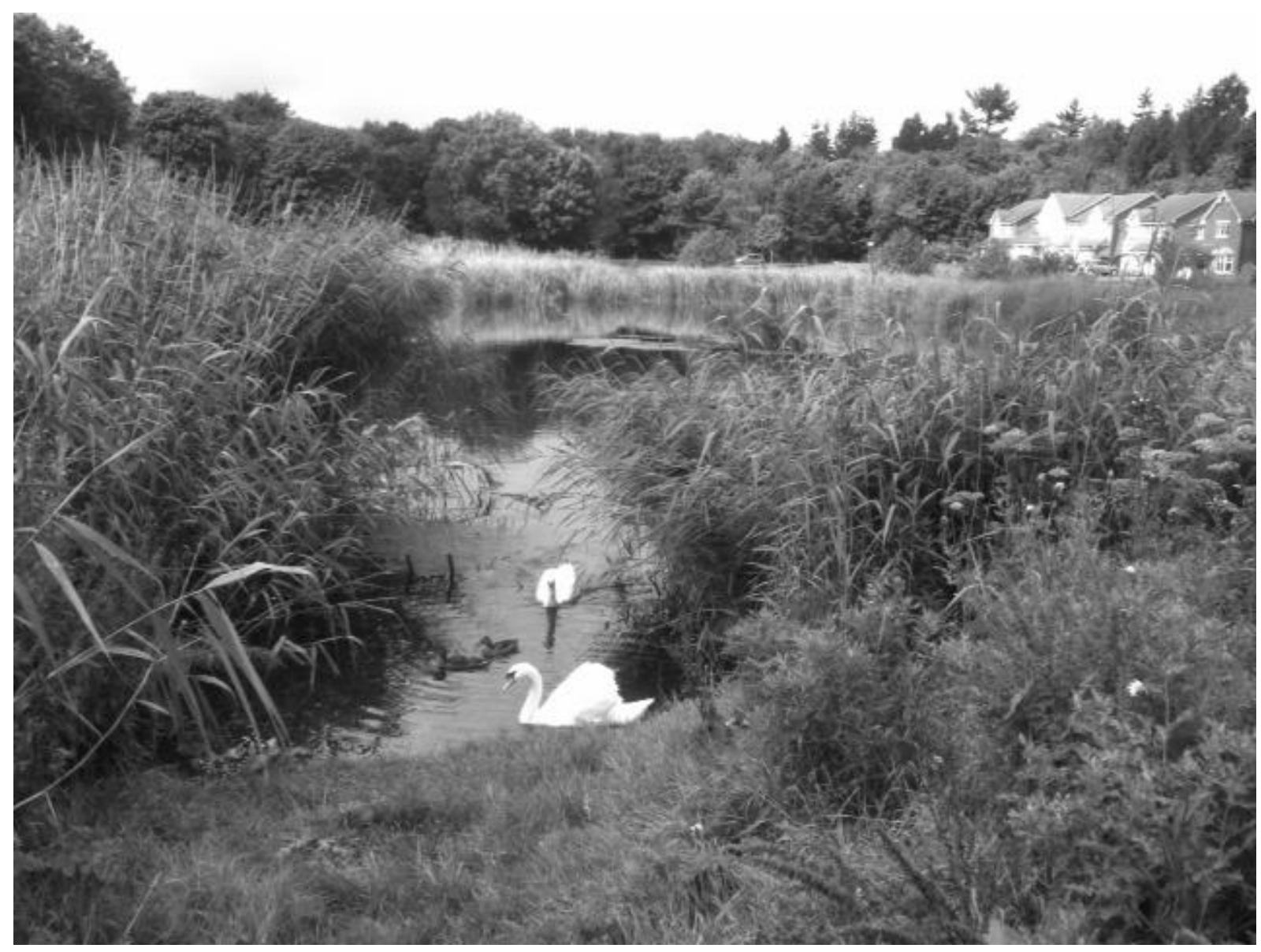

$<$ FCN $>$ Figure 15.4. $<$ FC $>$ SuDS pond in Ardler, Dundee, Scotland. The pond provides regulating ESs (flood reduction and water quality improvement) by slowing the flow of surface run-off from the surrounding residential development and by retaining the sediments and pollutants which are carried by the run-off. Additional ES are being provided by the pond; the water and vegetation are providing a habitat for nesting and visiting birds and for insects and pollinators. In addition, aesthetic and recreational ecosystem benefits are provided, as the local residents enjoy looking at and walking to the pond to view the birds (Jose et al., 2015). Preferred views such as this can increase house prices adjacent to SuDS features. Photo credit: Rebecca Wade 2016.

$<\mathrm{P}>$ While poor-quality waterbodies may at first appear to exclude the generation of services such as the supply of genetic information, the presence of species able to tolerate and/or degrade elevated pollutant levels offers interesting opportunities in relation to, for example, the field of 
microbial bioremediation (Galvao et al., 2005). The potential for plants, bacteria, and fungi which can degrade or immobilise organic and inorganic pollutants has received considerable attention (Desai et al., 2010), with drivers such as the EU Environmental Quality Standards Directive (2008) providing a strong impetus for the development of cost-effective technologies to mitigate identified and emerging priority substances.

\section{$<$ HA >15.6. Conclusions}

$<\mathrm{P}>$ As urbanisation increases, urban pollution impacts on ES will also increase. While good progress has clearly been made in evidence gathering, and in some areas of policy development and practice, more work effort is still required in order to achieve pollution reduction and ES provision. Urban planners, architects, and landscape architects, along with policymakers, need to continue their efforts to consider how natural resources and urban green infrastructure can be strategically developed and managed sustainably to meet the needs of urban populations. The valuation of ESs (including the services associated with urban pollution reduction) can support urban decision-making and budget planning, and contribute to reduce costs and improve people's well-being.

$<\mathrm{P}>$ Demuzere et al. (2014) are optimistic in their assessment of the impact of green infrastructure on climate change; they state that if green infrastructure continues to be applied in its current state, climate change adaptation benefits will be achieved, as long as it is based on a synergistic relationship with biodiversity conservation and ES efforts. This contribution marks progress towards a more climate-proofed future, but also marks an opportunity unfulfilled. The multi-functionality of green infrastructure characterises environmental policies that will make the most significant contribution in the future by being both politically popular and scientifically robust. It is also this multifunctional ability that currently underpins the majority of the potential weaknesses of green infrastructure. While achieving multiple 
objectives simultaneously may not be an unprecedented approach, it is clearly one that stakeholders at each level have yet to master. It requires effective interdisciplinary working and cooperation across policy sectors, and this in itself poses a perpetual challenge for environmental governance generally, not just for green infrastructure alone.

$<\mathrm{P}>$ Reduction of pollution and emissions is surely the first and best approach to tackling the impacts of urban pollution on ES. In combination with a reduction in emissions, the ecosystem benefits that urban greening offers must also be recognised and enhanced. For instance, unlike exhaust-pipe-based emission reduction strategies, greening also offers multiple benefits, including reduced surface temperature and noise pollution, and increased biodiversity and amenity value (Pugh et al., 2012). But it also offers challenges in ensuring vegetation health and minimising damage to non-green infrastructure (e.g. tree roots damaging underground water infrastructure pipes), and in recognising and minimising the disbenefits as well as the benefits.

\section{References}

Baldocchi, D.D., Hicks, B.B., and Camera, P. (1987). A canopy stomatal resistance model for gaseous deposition to vegetated surfaces. Atmospheric Environment, 21, 91-101.

Bidwell, R.G.S. and Fraser, D.E. (1972) Carbon monoxide uptake and metabolism by leaves. Canadian Journal of Botany, Vol. 50, No. 7: pp. 1435-1439. https://doi.org/10.1139/b72-174

Currie, B.A. and Bass, B. (2008) Estimates of air pollution mitigation with green plants and green roofs using the UFORE model. Urban Ecosystems, 11, 409-422. doi 10.1007/s11252008-0054-y https://link.springer.com/article/10.1007/s11252-008-0054-y

Davies, L., Kwiatkowski, L., Gaston, K.J., Beck, H., Brett, H., Batty, M., Scholes, L., Wade, R., Sheate, W.R., Sadler, J., Perino, G., Andrews, B., Kontoleon, A., Bateman, I., and Harris, 
J.A. (2011) Chapter 10 Urban. In The UK National Ecosystem Assessment Technical Report. UNEP-WCMC, Cambridge.

DEFRA (2013) Ecosystems Services Guidance. Published online by Department for Environment, Food and Rural Affairs: Guidance documents: Environmental management (Assessing environmental impact). https://www.gov.uk/guidance/ecosystems-services

Demuzere, M., Orru K., Heidrich O., Olazabal E., Geneletti D., Orru H., Bhave A.G., Mittal N., Feliu E., and Faehnle M.. (2014) Mitigating and adapting to climate change: Multifunctional and multi-scale assessment of green urban infrastructure. Journal of Environmental Management, 146, 107-115. http://ac.els-cdn.com/S0301479714003740/1-s2.0$\underline{\text { S0301479714003740-main.pdf? tid=2c4388e8-2e80-11e7-a8c7- }}$ $\underline{00000 a a b 0 f 6 b \& a c d n a t=1493651549 \_2 \mathrm{fc} 72 \mathrm{a} 0 \mathrm{dca} 2 \mathrm{fdb} 7 \mathrm{f} 8 \mathrm{f} 17 \mathrm{dc} 9 \mathrm{a} 5 \mathrm{be} 237 \mathrm{fc}}$

Desai, C., Pathak, H., and Madamwar, D. (2010) Advances in molecular and '-omics' technologies to gauge microbial communities and bioremediation at xenobiotic/anthropogen contaminated sites. Bioresource Technology, 101 (6), 1558-1569.

European Union (EU) Environmental Quality Standards Directive (2008) Directive 2008/105/EC of the European Parliament and of the Council of 16 December 2008 on Environmental Quality Standards in the Field of Water Policy. Available at: http://ec.europa.eu/environment/water/water-dangersub/index.htm European Union (EU) Floods Directive (2007) Directive 2007/60/EC of the European Parliament and of the Council of 23 October 2007 on the Assessment and Management of Flood Risks. Available at: http://eurlex.europa.eu/LexUriServ/LexUriServ.do?uri=OJ:L:2007:288:0027:01:EN:HTML 
European Union (EU) Water Framework Directive (WFD) (2000) Directive 2000/60/EC of the European Parliament and of the Council of 23 October 2000 Establishing a Framework for Community action in the Field of Water Policy Water Framework Directive. Available at: http://eur-lex.europa.eu/LexUriServ/LexUriServ.do?uri=CELEX:32000L0060:EN:HTML Galvao, T.C., Mohn, W.W., and Lorenzo, V. (2005) Exploring the microbial biodegradation and biotransformation gene pool. Trends in Biotechnology, 23, 497-506.

GCV Green Network Partnership (no date) Integrating Green Infrastructure. http://www.gcvgreennetwork.gov.uk/igi/introduction

Jose, R., Wade, R., and Jefferies, C. (2015) Recognising the multiple-benefit potential of SUDS. Water Science \& Technology, 71.2.

Kallis, G. and Butler, D. (2001) The EU water framework directive: Measures and implications. Water Policy, 3, 125-142.

Kiss, M., Takács, A., Pogácsás, R., and Gulyás, A. (2015). The role of ES in climate and air quality in urban areas: Evaluating carbon sequestration and air pollution removal by street and park trees in Szeged (Hungary). Moravian Geographical Reports, 23, 3/2015. https://www.itreetools.org/eco/resources/int_research/2015Mar_Kiss_Szeged_Hungary_Eco_ $\underline{\text { Journal.pdf }}$

Kong, F., Yin, H., Nakagoshi, N., and Zong, Y. (2010) Urban green space network development for biodiversity conservation: Identification based on graph theory and gravity modeling. Landscape and Urban Planning, 95, 16-27.

Lundy, L. and Wade, R. (2011) Integrating sciences to sustain urban ecosystem services. Progress in Physical Geography, 35, 653. doi: 10.1177/0309133311422464 
MA (2005) Millennium Ecosystem Assessment, Ecosystems and Human Well-Being: Synthesis, 2005, Washington, DC: Island Press.

Maes, J., Polce, C., Zulian, G., Vandecasteele, I., Perpina, C., Rivero, I., Guerra, C., Vallecillo, S., Vizcaino, P., and Hiederer, R. (2017) Ecosystem services mapping. Chapter 5 in Benjamin Burkhard and Joachim Maes (eds.), Mapping Ecosystem Services. Pensoft Publishers, Bulgaria.

Pérez-Navarro Gómez, Á., Morales Torres, A., Peñalvo López, E., Andrés Doménech, I., Alfonso Solar, D., Perales Momparler, S., and Pablo Peris García, P. (2015) Report on the Green Roof Monitoring in Benaguasil. Part of the EU MED E²STORMED PROJECT (Improvement of energy efficiency in the water cycle by the use of innovative storm water management in smart Mediterranean cities) www.e2stormed.eu

POSTnote 281. (2007) Ecosystem Services. March 2007.

POSTnote 376. (2011) Natural Capital Accounting. May 2011.

POSTnote 542. (2016) Natural Capital: An Overview. December 2016.

Pugh, T.A.M., MacKenzie, A.R., Whyatt, J.D., and Hewitt, C.N. (2012) Effectiveness of green infrastructure for improvement of air quality in urban street canyons. Environmental Science \& Technology, 46, 7692-7699. http://citiesalive.greenroofs.org/resources/GreenInfrastructurePaper.pdf

Rogers, C.A., Wayne, P.M., Macklin, E.A., Muilenberg, M.L., Wagner, C.J. et al. (2006) Interaction of the onset of spring and elevated atmospheric $\mathrm{CO}_{2}$ on ragweed (Ambrosia artemisiifolia) pollen production. Environmental Health Perspectives, 114, 865-869. 
Salmond, J.A., Tadaki, M., Vardoulakis, S., Arbuthnott, K., Coutts, A., Demuzere, M., Dirks, K.M., Heaviside, C., Lim, S., Macintyre, H., McInnes, R.N., and Wheeler, B.W. (2014)

Health and climate related ecosystem services provided by street trees in the urban environment. From The 11th International Conference on Urban Health Manchester, UK. 6 March 2014. Environmental Health, 2016, 15 (Suppl 1):36. doi 10.1186/s12940-016-0103-6. https://ehjournal.biomedcentral.com/articles/10.1186/s12940-016-0103-6

Säumel, I., Weber, F., and Kowarik, I. (2016) Toward livable and healthy urban streets: Roadside vegetation provides ecosystem services where people live and move. Environmental Science \& Policy, 62, 24-33.

Scot Gov (2011) The Flood Risk Management (Scotland) Act 2009 - Sustainable Flood Risk Management - Principles of Appraisal: A Policy Statement.

http://www.gov.scot/Publications/2011/07/20125533/0

URBES (2013) Valuing Ecosystem Services in Urban Areas. URban Biodiversity and Ecosystems Services (URBES) Project. Factsheet 3. www.urbesproject.org

Wentworth, J. (2017) Urban Green Infrastructure and Ecosystem Services. POST brief Number 26, July 2017.

WHO (2016) Ambient (Outdoor) Air Quality and Health. Fact sheet. http://www.who.int/mediacentre/factsheets/fs313/en/

Wise, S. (2008) GI Rising - Best Practices in Stormwater Management. American Association of Planners. August/September 2008. 